\title{
Flow-Injection Iodimetric Determination of Captopril in Pharmaceutical Preparations
}

\author{
Erlando Schmidt Jr., Wanessa R. Melchert and Fábio R. P. Rocha* \\ Instituto de Química, Universidade de São Paulo, CP 26077, 05513-970 São Paulo-SP, Brazil
}

\begin{abstract}
Um procedimento simples, rápido e de baixo custo é descrito para a determinação de captopril em preparações farmacêuticas. O procedimento é baseado em um sistema de análises por injeção em fluxo explorando a formação em linha de triiodeto, o qual é consumido na presença do analito gerando um sinal transiente. Resposta linear foi observada até $200 \mu \mathrm{mol} \mathrm{L} \mathrm{L}^{-1}$ com limite de detecção de $1,0 \mu \mathrm{mol} \mathrm{L}^{-1}(99,7 \%$ de confiança). O coeficiente de variação $(\mathrm{n}=20)$ e a freqüência de amostragem foram estimados em 1,2\% e 72 determinações por hora, respectivamente. Os principais excipientes encontrados em preparações farmacêuticas não afetaram a determinação de captopril. Reamostragem na zona dispersa foi explorada para implementar diluições em linha, visando a análise direta de suspensões das amostras. Resultados da análise de amostras comerciais foram concordantes com os obtidos pelo procedimento volumétrico de referência descrito na Farmacopéia americana com nível de confiança de $95 \%$. O consumo de reagente foi estimado em $18 \mu \mathrm{g} \mathrm{KMnO}_{4}$ e $10 \mathrm{mg}$ KI por determinação, com custo de US\$2,50 por 1000 determinações.
\end{abstract}

A simple, fast and low cost procedure for spectrophotometric determination of captopril in pharmaceutical preparations is described. The procedure is based on a flow-injection system exploiting the on-line formation of the triiodide reagent, which is consumed in the presence of the analyte generating a transient signal. Linear response was observed up to $200 \mu \mathrm{mol} \mathrm{L} \mathrm{L}^{-1}$ with a detection limit of $1.0 \mu \mathrm{mol} \mathrm{L}-1$ (99.7\% confidence level). The coefficient of variation $(\mathrm{n}=20)$ and the sampling rate were estimated as $1.2 \%$ and 72 determinations per hour, respectively. The main excipients found in pharmaceutical preparations did not affect the captopril determination. The zone sampling approach was exploited to implement on-line dilutions, aiming direct analysis of sample extracts. Results of the analysis of commercial samples agreed with the obtained by the titrimetric reference procedure described in the US-Pharmacopeia at the $95 \%$ confidence level. The reagent consumption was estimated as $18 \mu \mathrm{g}$ of $\mathrm{KMnO}_{4}$ and $10 \mathrm{mg}$ of $\mathrm{KI}$ per determination, with a cost of US\$2.50 per 1000 determinations.

Keywords: flow injection, spectrophotometry, iodimetry, captopril, anti-hypertensive

\section{Introduction}

Arterial hypertension is one of the diseases with major prevalence in the world, being estimated that one in six habitants is affected by this health problem. Although caused by still unknown factors, some risk factors contribute to the development of this pathology, like family history, age, high salt intake, obesity, sedentariness, alcoholism and stress. ${ }^{1}$ In Brazil, it is estimated that 15 to $20 \%$ of adult population is affected by this disorder. ${ }^{2}$

The first drug planned to be used for arterial hypertension treatment was captopril, 1-[(2S)-3-mercapto2-methylpropionyl]-L-proline (Figure 1), which belongs to the class of angiotensin-converting enzyme (ACE) inhibitors. This drug interacts with ACE due to its similarity with a dipeptide and the sulphydryl group also plays an important role, linking covalently to the zinc atom in the enzyme active site. This drug is widely used mainly for arterial hypertension treatment, but also in diabetic nephropathy and congestive cardiac insufficiency..$^{3-5}$

Captopril determination in pharmaceuticals is usually performed by volumetry or high performance liquid<smiles>C[C@H](CS)C(=O)N1CCC[C@H]1C(=O)O</smiles>

Figure 1. Molecular structure of captopril. 
chromatography (HPLC), as described in the United States Pharmacopeia. ${ }^{6}$ The volumetric procedure is based on captopril titration in acid medium using an iodine solution in presence of excess of iodide, with starch as indicator. Although precise and exact, the procedure is time-consuming. HPLC procedures need expensive and complex equipment, also consuming significant amounts of solvents. These drawbacks hinder the use of these procedures for routine analysis.

Flow injection systems have been employed specially for mechanization of analytical procedures, in order to minimize the analyst intervention, enhancing the number of samples processed by time and improving precision. These systems also show a great potential for development of greener analytical procedures, with reduced waste production when compared to the batch ones. ${ }^{7,8}$

Some flow-based procedures for captopril determination were presented, exploiting detection by spectrophotometry, ${ }^{9-13}$ chemiluminescence ${ }^{14-21}$ or biamperometry. ${ }^{22}$ These procedures use heavy metals, ${ }^{9}$ reagents hazardous to the environment ${ }^{10}$ or present problems related to precision ${ }^{15}$ and sensitivity. ${ }^{12}$

In this work, it is described a flow-based analytical procedure for captopril determination with spectrophotometric detection based on the consumption of triiodide. The zone sampling strategy ${ }^{23}$ was exploited for on-line dilutions, aiming the direct analysis of extracts of pharmaceutical preparations.

\section{Experimental}

\section{Apparatus}

The flow systems were constructed with slidingbar injectors, $0.7 \mathrm{~mm}$ i.d. polyethylene tubes and Perspex joint points. An injector with electronic time-control (Micronal) was used for on-line sample dilution. An Ismatec IPC-8 peristaltic pump equipped with Tygon tubes was used for fluid propelling. An UV-Vis spectrophotometer (Hitachi, U-3000) with a $10 \mathrm{~mm}$ optical path $(80 \mu \mathrm{L}$ inner volume) quartz flow cell (Hellma) was employed for signal measurements. The spectrophotometer was interfaced to a Pentium II microcomputer in order to adjust instrumental parameters and data acquisition.

\section{Reagents and solutions}

All solutions were prepared with analytical grade chemicals and distilled-deionized water. Captopril was supplied by Pharma Nostra (http://www.pharmanostra.com. br/2006) and other chemicals were purchased from Merck.
The reference solutions were prepared in the range 5.0$200 \mu \mathrm{mol} \mathrm{L}^{-1}$ by dilution of a $5.0 \mathrm{mmol} \mathrm{L}^{-1}$ stock solution, prepared by dissolving $54.3 \mathrm{mg}$ captopril in water to a final volume of $50 \mathrm{~mL}$. The stock solution was previously standardized by iodimetric titration. ${ }^{6}$

A $45 \mu \mathrm{mol} \mathrm{L}{ }^{-1}$ potassium permanganate solution $\left(\mathrm{R}_{1}\right)$ was daily prepared by dissolving $5.9 \mathrm{mg} \mathrm{KMnO}_{4}$ in $250 \mathrm{~mL}$ of $9.0 \mathrm{mmol} \mathrm{L}^{-1}$ sulfuric acid. A $80 \mathrm{mmol} \mathrm{L}^{-1}$ potassium iodide solution $\left(\mathrm{R}_{2}\right)$ was weekly prepared by dissolving $3.32 \mathrm{~g}$ of $\mathrm{KI}$ in $250 \mathrm{~mL}$ of water.

The effect of some species commonly present as excipients in commercial pharmaceutical preparations was evaluated. For compounds of low solubility in water, like microcrystalline cellulose, magnesium stearate, stearic acid and starch, suspensions were prepared from $0.1 \mathrm{~g}$ of solid in $50 \mathrm{~mL}$ of a solution containing a fixed amount of captopril $\left(70 \mu \mathrm{mol} \mathrm{L}^{-1}\right)$. The mixtures were shaken for $10 \mathrm{~min}$, followed by 5 minutes of centrifugation, filtration and analysis in the proposed flow system. The effect of the water soluble species (i.e. lactose, glucose and sucrose) was evaluated in concentrations up to 500 times higher than captopril, maintained as $70 \mu \mathrm{mol} \mathrm{L}-1$.

\section{Sample preparation}

Samples were purchased at local drugstores. The pharmaceutical preparations contained as excipients microcrystalline cellulose, starch, lactose, magnesium stearate, stearic acid, sodium croscarmellose and silicon dioxide. Fifteen tablets of each medicine were finely powdered. For the procedure with manual dilution (Figure 2a), a mass $c a$. $500 \mathrm{mg}$ was shaken in $200 \mathrm{~mL}$ of deionized water for $15 \mathrm{~min}$. The resulting mixture was filtered through a filter paper and the filtrate diluted with water to $250 \mathrm{~mL}$. This solution was diluted with water to $c a$. $30 \mu \mathrm{mol} \mathrm{L-1}$ captopril, according to the labeled value. For the analysis with zone sampling, a mass $c a$. $200 \mathrm{mg}$ was shaken in $50 \mathrm{~mL}$ of deionized water for $15 \mathrm{~min}$. After centrifugation for $10 \mathrm{~min}$, the supernatants were directly introduced in the flow system described in Figure $2 b$.

\section{Flow diagram and procedure}

The flow diagram of the system for captopril determination with previous sample dilution is presented in Figure 2a. In the position showed, sample ( $\mathrm{S}$ ) is aspirated to fill the $300 \mu \mathrm{L}$ loop $\left(\mathrm{L}\right.$ ), while $\mathrm{R}_{1}$ and $\mathrm{R}_{2}$ are mixed at the joint point $Y$. The reaction between permanganate and iodide is developed through the $50 \mathrm{~cm}$ long coil $\left(\mathrm{B}_{1}\right)$ producing on-line the triiodide reagent. The baseline is established in function of radiation absorption by the reagent mixed with the carrier stream. In the alternative resting position of the 
a

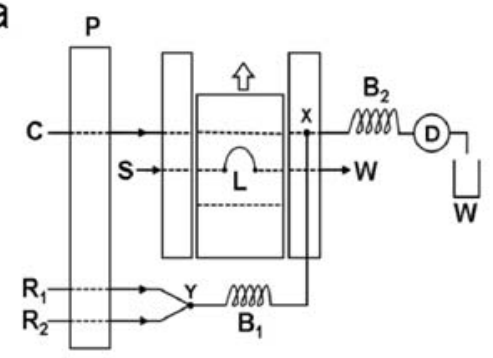

b

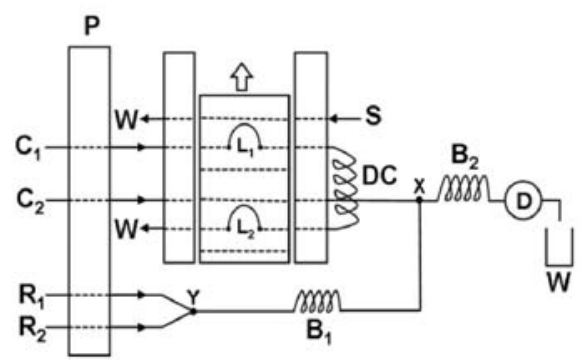

Figure 2. Flow diagram of the system for captopril determination with (a) manual or (b) on-line sample dilution. P: Peristaltic pump; S: Sample; C, $\mathrm{C}_{1}$, $\mathrm{C}_{2}$ : Carrier streams (water, $3.0 \mathrm{~mL} \mathrm{~min}^{-1}$ ); DC: $100 \mathrm{~cm}$ dispersion coil; $\mathrm{B}_{1}$, $\mathrm{B}_{2}: 50$ and $200 \mathrm{~cm}$ coiled reactors, respectively; $\mathrm{R}_{1}: 45 \mu \mathrm{mol} \mathrm{L}^{-1} \mathrm{KMnO}_{4}$ in $9.0 \mathrm{mmol} \mathrm{L}^{-1} \mathrm{H}_{2} \mathrm{SO}_{4}\left(3.0 \mathrm{~mL} \mathrm{~min}^{-1}\right) ; \mathrm{R}_{2}: 80 \mathrm{mmol} \mathrm{L}^{-1} \mathrm{KI}\left(0.9 \mathrm{~mL} \mathrm{~min}^{-1}\right) ; \mathrm{L}$, $\mathrm{L}_{2}: 300 \mu \mathrm{L}$ and $\mathrm{L}_{1}: 50 \mu \mathrm{L}$ sample loops; $\mathrm{D}$ : Spectrophotometer $(\lambda=350 \mathrm{~nm})$; $\mathrm{X}$ and $\mathrm{Y}$ : confluence joint points and $\mathrm{W}$ : Waste vessel.

commutator, sample is inserted into the water carrier stream (C), being mixed at the joint point $\mathrm{X}$ with the produced triiodide. The oxidation of captopril occurs in a $200 \mathrm{~cm}$ long coil $\left(\mathrm{B}_{2}\right)$ and the analytical signal was based on the diminution of the absorbance at $350 \mathrm{~nm}$ related to the consumption of triiodide. The spectrophotometer software was employed for data acquisition and measurements were based on peak height and carried out in triplicate.

The flow diagram of the system for dilution by zone sampling ${ }^{23}$ is shown in Figure 2b. In the position showed, a $50 \mu \mathrm{L}$ sample aliquot is inserted in the carrier $\mathrm{C}_{1}$, being dispersed at the coil DC. After a previously defined time interval $\left(\mathrm{ts}_{1}\right)$, the injector is moved back to the alternative resting position and a tail portion of the dispersed sample zone is inserted into the carrier $\mathrm{C}_{2}$. Sample and reagent mixing occurs in coil $\mathrm{B}_{2}$ and measurement was carried out as previously described.

The procedure described in the United States Pharmacopeia, based on iodimetric titration, ${ }^{6}$ was used as reference for the analysis of commercial samples.

\section{Results and Discussion}

\section{General aspects}

The spectrophotometric determination was based on consumption of triiodide $\left(\mathrm{I}_{3}^{-}\right)$by captopril. Potassium permanganate in acid medium oxidizes iodide to generate iodine (equation 1). In excess of iodide, iodine forms the triiodide complex (equation 2), which absorbs at $350 \mathrm{~nm}$. Captopril reduces triiodide to iodide (equation 3), due to the sulphydryl group linked to the carbonic chain (Figure 1). Other reagents do not absorb at the measured wavelength.

$$
\begin{aligned}
& 2 \mathrm{MnO}_{4}^{-}+10 \mathrm{I}^{-}+16 \mathrm{H}^{+} \rightarrow 2 \mathrm{Mn}^{2+}+5 \mathrm{I}_{2}+8 \mathrm{H}_{2} \mathrm{O} \\
& \mathrm{I}_{2}+\mathrm{I}^{-} \rightarrow \mathrm{I}_{3}^{-} \\
& \mathrm{I}_{3}^{-}+2 \mathrm{C}_{8} \mathrm{H}_{14} \mathrm{O}_{3} \mathrm{NC}-\mathrm{SH} \rightarrow \\
& \quad 3 \mathrm{I}^{-}+\mathrm{C}_{8} \mathrm{H}_{14} \mathrm{O}_{3} \mathrm{NC}-\mathrm{S}-\mathrm{S}-\mathrm{CNO}_{3} \mathrm{H}_{14} \mathrm{C}_{8}+2 \mathrm{H}^{+}
\end{aligned}
$$

Preliminary measurements were carried out by using starch as indicator, added to the $\mathrm{R}_{2}$ solution. The sensitivity obtained with the indicator $\left(4828 \mathrm{~L} \mathrm{~mol}^{-1}\right)$ was similar to the attained without the indicator $\left(4907 \mathrm{~L} \mathrm{~mol}^{-1}\right)$ at the wavelengths of maximum absorption (580 and $350 \mathrm{~nm}$, respectively), but linearity was better in the absence of starch $(r=0.999)$. With continuous use of the reagent containing starch, it was observed the impregnation of the blue-violet product in the tubes and flow cell, causing baseline drift $\left(c a .0 .2 \mathrm{~h}^{-1}\right)$. In addition, it was necessary to prepare the starch solution daily to avoid fungus growth, which hinders the indicator property. The utilization of starch was avoided in view of these drawbacks. Absorption spectra of several extracts of sample preparations showed that absorption occurs only for wavelengths lower than $240 \mathrm{~nm}$. Thus, measurements at $350 \mathrm{~nm}$ (wavelength of maximum absorption of $\mathrm{I}_{3}^{-}$) would not be affected by the sample components.

\section{System optimization}

The relevant hydrodynamic and chemical parameters were optimized by the univariate method, by considering the magnitude of the analytical signal, precision, reagent consumption and the absorbance value corresponding to the baseline. The ranges evaluated of each variable and the selected values are presented in Table 1.

Table 1. Optimized parameters to the proposed system

\begin{tabular}{lcc}
\hline Parameter & Range studied & Selected value \\
\hline Sample loop / $\mu \mathrm{L}$ & $150-450$ & 300 \\
$\mathrm{R}_{1}$ flow-rate / $\left(\mathrm{mL} \mathrm{min}^{-1}\right)$ & $0.9-3.0$ & 3.0 \\
$\mathrm{R}_{2}$ flow-rate / $\left(\mathrm{mL} \mathrm{min}^{-1}\right)$ & $0.9-3.0$ & 0.9 \\
$\mathrm{KMnO}_{4}$ concentration / $\left(\mu \mathrm{mol} \mathrm{L}^{-1}\right)$ & $45-150$ & 45 \\
$\mathrm{KI}$ concentration / $\left(\mathrm{mmol} \mathrm{L}^{-1}\right)$ & $0.8-160$ & 80 \\
$\mathrm{~B}_{1}$ length / cm & $25-150$ & 50 \\
$\mathrm{~B}_{2}$ length / cm & $100-300$ & 200 \\
\hline
\end{tabular}


The effect of concentration and flow-rate of both reagents are presented in Figure 3. In the former experiment (Figure 3I), the reagent flow-rates were kept constant (3.0 and $1.2 \mathrm{~mL} \mathrm{~min}^{-1}$ for $\mathrm{R}_{1}$ and $\mathrm{R}_{2}$, respectively) while the reagent concentrations were varied. The effect of the reagent amount in the sample zone was then evaluated without significant changes in sample dispersion. The oxidant concentration limits the amount of $\mathrm{I}_{3}^{-}$generated, and thus the magnitude of the baseline, because $\mathrm{KI}$ is used in excess. In the range 15-60 $\mu \mathrm{mol} \mathrm{L} \mathrm{L}^{-1}$, the oxidant concentration affected only slightly the analytical signal (Figure 3Ia). The permanganate concentration was thus fixed as $45 \mu \mathrm{mol} \mathrm{L} \mathrm{L}^{-1}$ because the baseline kept close to absorbance $=1.0$, maximizing the linear range and reducing the error related to the spectrophotometric measurements. The effect of KI concentration was then evaluated (Figure 3Ib) and the analytical signal increased up to $80 \mathrm{mmol} \mathrm{L}^{-1}$. This concentration was selected for further studies in order to maximize the analytical response with minor reagent consumption. In the second experiment, reagent flow-rates were evaluated between 0.9 and $3.0 \mathrm{~mL}$ $\mathrm{min}^{-1}$ at the concentrations previously defined. In Figure 3II, similar results were obtained for both reagents, indicating that diminution of the analytical signal with the flow-rate was related to sample dilution. The KI flow-rate was then maintained as $0.9 \mathrm{~mL} \mathrm{~min}^{-1}$ to minimize this effect and
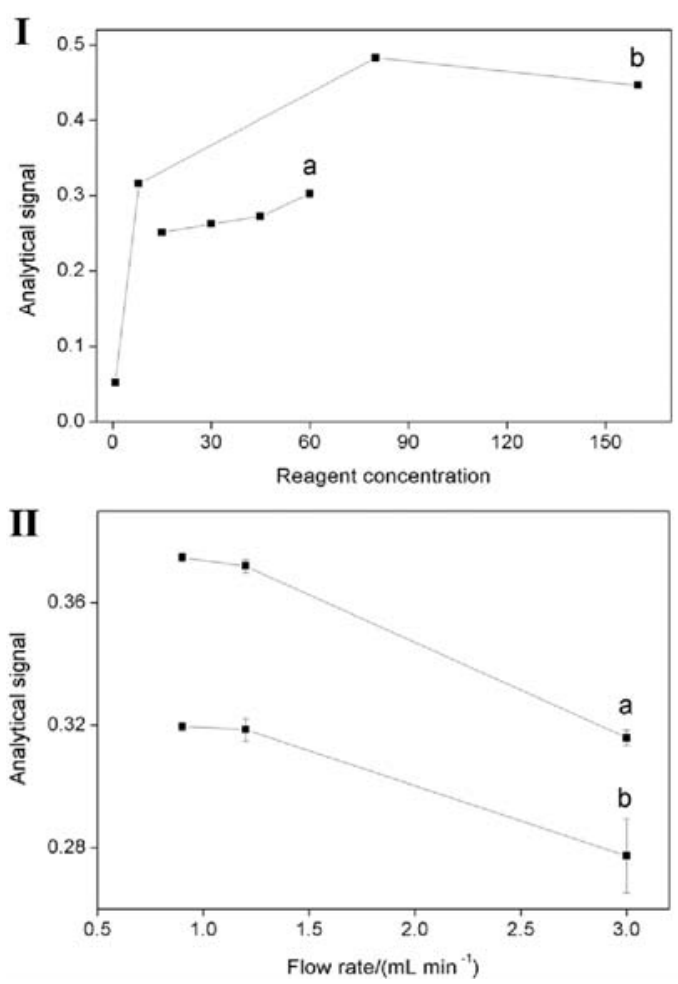

Figure 3. Effect of reagent concentration (I) and flow rate (II) on the analytical signal: (a) $\mathrm{KMnO}_{4}$ and (b) $\mathrm{KI}$. $\mathrm{KMnO}_{4}$ and $\mathrm{KI}$ concentrations in $\mu \mathrm{mol} \mathrm{L} \mathrm{L}^{-1}$ and $\mathrm{mmol} \mathrm{L}^{-1}$, respectively. All measurements were carried out at $350 \mathrm{~nm}$. reagent consumption. However, in disagreement with the observed when the $\mathrm{KMnO}_{4}$ flow-rate was $3.0 \mathrm{~mL} \mathrm{~min}$, calibration curves were not linear $(r<0.992)$ when $R_{1}$ reagent was introduced at $0.9 \mathrm{~mL} \mathrm{~min}^{-1}$, even when the concentration was increased to $150 \mu \mathrm{mol} \mathrm{L}^{-1}$. This observation is related to the higher sample dilution when the flow-rate of the confluent stream is increased, resulting in a higher excess of triiodide in relation to captopril. Thus, flow-rates of the reagents $R_{1}$ and $\mathrm{R}_{2}$ were maintained as 3.0 and $0.9 \mathrm{~mL} \mathrm{~min}{ }^{-1}$, respectively, yielding baseline absorbance values close to 1.0 and linear calibration curves $(r>0.999)$.

The length of the reactor coil $\mathrm{B}_{1}$, which affects reagent mixing conditions and the residence time for generation of triiodide, was evaluated between 25 and $150 \mathrm{~cm}$. Stable baselines were obtained for reactor coils longer than $50 \mathrm{~cm}$. As the analytical signal was only slightly different for the evaluated reactor lengths (variations lower than 7\%), a $50 \mathrm{~cm}$ reactor was selected for further studies. The length of the reactor coil $\mathrm{B}_{2}$ is an important parameter which affects mixing conditions and defines the residence time for reagent reduction by captopril, as well as sample dispersion. It was evaluated in a batch experiment that the reduction of triiodide by captopril is relatively fast, achieving the steadystate condition after $c a$. $5 \mathrm{~s}$. The results obtained by varying the coil length between 100 and $300 \mathrm{~cm}$ were in agreement with the observation that the analytical signal diminishes by increasing the reactor coil in view of the sample dispersion. Despite the analytical signal decreased $10 \%$ in relation to the achieved with a $100 \mathrm{~cm}$ long reactor, a $200 \mathrm{~cm}$ coil was selected in view of lower baseline noise.

The effect of the sample volume was evaluated between 150 and $450 \mu \mathrm{L}$. A $300 \mu \mathrm{L}$ sample loop was selected because the analytical response was only $7.2 \%$ lower than that obtained with a $450 \mu \mathrm{L}$ loop, while the washing time increased $40 \%$ for the higher sample loop, which could affect the sampling rate.

\section{Analytical features}

In the optimized conditions, stable baselines and good precision were achieved (Figure 4 ) with linear response up to $200 \mu \mathrm{mol} \mathrm{L} \mathrm{L}^{-1}$, described by the equation $\Delta \mathrm{A}=(0.02116 \pm$ $0.00028)+(0.00465 \pm 0.00001) \times \mathrm{C}(\mathrm{r}=0.999)$, in which $\Delta \mathrm{A}$ is the absorbance variation at $350 \mathrm{~nm}$ and $\mathrm{C}$ is the captopril concentration in $\mu \mathrm{mol} \mathrm{L} \mathrm{L}^{-1}$. The detection limit was estimated as $1.0 \mu \mathrm{mol} \mathrm{L}^{-1}$ from the standard deviation of 20 measurements of the blank solution, according to IUPAC recommendations ${ }^{24}$ at the $99.7 \%$ confidence level. The coefficient of variation $(\mathrm{n}=20)$ and sampling rate were estimated as $1.2 \%$ and 72 determinations per hour, respectively. 


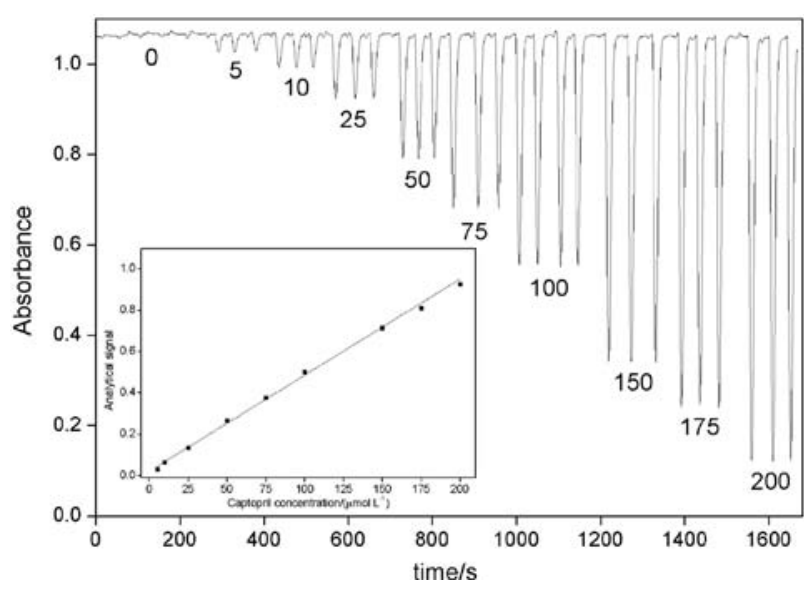

Figure 4. Transient signals obtained for different captopril concentrations. The inset shows the corresponding calibration graph. Numbers indicate concentrations in $\mu \mathrm{mol} \mathrm{L} \mathrm{L}^{-1}$.

The analytical features of the proposed procedure were comparable or superior to the obtained in others flowbased procedures for the anti-hypertensive determination, as showed in Table 2.9-22 Sensitivity was 2.9 to 26 -fold higher than the achieved in previous spectrophotometric procedures with measurements in the visible, ${ }^{9-13}$ however, lower than the obtained in procedures based on chemiluminescence. ${ }^{14-21}$ On the other hand, selectivity is a critical aspect in these procedures, because the sample matrix has a significant effect on the chemiluminescence intensity. ${ }^{25}$ The linear response and coefficient of variation are comparable to the observed in other procedures. The sampling rate is quite satisfactory for routine analysis and low amounts of low cost reagents largely available in most analytical laboratories are consumed. In opposition, some procedures use expensive reagents ${ }^{9}$ or in large amounts (e.g. $4.0 \mathrm{~mol} \mathrm{~L}^{-1}$ sulfuric acid ${ }^{16}$ ) or, still, generate toxic wastes containing hazardous compounds, as 1,10-phenantroline, hydrazone species, formaldehyde and luminol. The reagent consumption was estimated as $18 \mu \mathrm{g} \mathrm{KMnO}_{4}, 10 \mathrm{mg} \mathrm{KI}$ and a quantity equivalent to $1.2 \mu \mathrm{L}$ of concentrated $\mathrm{H}_{2} \mathrm{SO}_{4}$ per determination. By considering the reagent amounts, the cost was estimated as US\$2.50 per 1000 determinations.

\section{Effect of excipients}

The effect of some species commonly present in captopril pharmaceutical formulations (lactose, glucose, sucrose, starch, stearic acid, magnesium stearate and microcrystalline cellulose) was evaluated in molar quantities

Table 2. Comparison of analytical features of flow procedures for captopril determination

\begin{tabular}{|c|c|c|c|c|c|}
\hline Method principle & $\mathrm{LOD} /(\mu \mathrm{mol} \mathrm{L}-1)$ & $\begin{array}{c}\text { Linear range / } \\
\left(\mu \mathrm{mol} \mathrm{L} \mathrm{L}^{-1}\right)\end{array}$ & $\begin{array}{r}\text { Coefficient of } \\
\text { variation / }(\%)\end{array}$ & Sampling rate $/ \mathrm{h}^{-1}$ & Reference \\
\hline Reaction with $\mathrm{PdCl}_{2}$ in $\mathrm{HCl}$ medium ${ }^{\mathrm{a}, 1}$ & 2.2 & $20-600$ & 0.6 & 90 & 9 \\
\hline $\begin{array}{l}\text { Reaction with } \mathrm{Fe}(\mathrm{III}) \text { and complexation of } \mathrm{Fe}(\mathrm{II}) \text { with } \\
\text { 1,10-phenantroline } \mathrm{e}^{\mathrm{a}, 2}\end{array}$ & 5.0 & $10-800$ & 0.2 & 60 & 10 \\
\hline $\begin{array}{l}\text { Inhibitory effect on formation of } \mathrm{Co}(\mathrm{II})-2,2^{\prime} \text {-dipyridil-2- } \\
\text { pyridilhydrazone in ethanol medium } \\
\text { a,3 }\end{array}$ & 12 & $<1200$ & 0.8 & 60 & 11 \\
\hline \multirow{2}{*}{$\begin{array}{l}\text { Reduction of } \mathrm{Fe}(\mathrm{III}) \text { to form } \mathrm{Fe}(\mathrm{II}) / 2,2^{2} \text {-dipyridil-2- } \\
\text { pyridilhydrazone complex in ethanol medium }\end{array}$} & 32 & $55-4600$ & 1.2 & 60 & \multirow{2}{*}{12} \\
\hline & 18 & $32-4600$ & 0.8 & 120 & \\
\hline $\begin{array}{l}\text { Reaction with iodate in the presence of iodide, kinetic } \\
\text { determination }{ }^{a, 5}\end{array}$ & - & $46-276$ & - & 100 & 13 \\
\hline $\begin{array}{l}\text { Enhancing effect of captopril on luminol/ferrycianide } \\
\text { reaction }^{\text {b,2 }}\end{array}$ & - & $0.46-180$ & 1.0 & 90 & 14 \\
\hline Enhancing effect of captopril on luminol/ $/ \mathrm{H}_{2} \mathrm{O}_{2}$ reaction ${ }^{\mathrm{b}, 1}$ & $9.2 \times 10^{-3}$ & $0.023-23$ & 3.1 & 180 & 15 \\
\hline $\begin{array}{l}\text { Reaction of captopril with } \mathrm{KMnO}_{4} \text { and formaldehyde in } \\
\mathrm{H}_{2} \mathrm{SO}_{4}{ }^{\mathrm{b}, 6}\end{array}$ & $5.1 \times 10^{-2}$ & $0.23-9.2$ & 1.2 & - & 16 \\
\hline $\begin{array}{l}\text { Complex formation with } \mathrm{Co}(\mathrm{II}) \text { and enhancing effect on } \\
\text { oxidation of luminol by dissolved } \mathrm{O}_{2}^{\mathrm{b}, 1}\end{array}$ & 0.01 & $0.032-4.6$ & 3.0 & 120 & 17 \\
\hline $\begin{array}{l}\text { Reaction with permanganate and quinine-sensitized } \\
\text { chemiluminescence }^{\mathrm{b}, 1}\end{array}$ & 0.03 & $0.1-4.6$ & 2.0 & 120 & 18 \\
\hline Reaction with electrogenerated $\mathrm{Ag}(\mathrm{II})^{\mathrm{b}, 1}$ & 0.03 & $0.92-46$ & 2.7 & 60 & 19 \\
\hline Reaction with electrogenerated $\mathrm{Mn}(\mathrm{III})^{\mathrm{b}, 1}$ & 0.08 & $0.3-100$ & - & - & 20 \\
\hline $\begin{array}{l}\text { Photochemical reaction with } \mathrm{Ce}(\mathrm{IV}) \text { sensitized by } \\
\text { rhodamine } 6 \mathrm{G}^{\mathrm{b}, 1}\end{array}$ & 0.2 & $1-200$ & 2.8 & 500 & 21 \\
\hline $\begin{array}{l}\text { Reaction with } \mathrm{Fe}(\mathrm{III}) \text { and biamperometric detection of } \\
\mathrm{Fe}(\mathrm{II})^{\mathrm{c}, 1}\end{array}$ & 0.05 & $0.14-16.6$ & 0.97 & 69 & 22 \\
\hline Consumption of $\mathrm{I}_{3}^{-}$produced on-line ${ }^{\mathrm{a}, 1}$ & 1.0 & $<200$ & 1.2 & 72 & Proposed system \\
\hline
\end{tabular}

Detection: a, spectrophotometry; b, chemiluminescence and c, amperometry. 1, FIA/confluent streams; 2, FIA/merging zones; 3, r-FIA; 4, sequential injection analysis; 5 , multipumping flow system; 6 , stopped-flow. 
up to 500 -fold superior to the analyte concentration. The solutions or suspensions were prepared with a fixed amount of captopril $\left.(70 \mu \mathrm{mol} \mathrm{L})^{-1}\right)$ and the results were compared with the obtained with a solution prepared without the concomitants. The maximum tolerated amount (interference lower than 5\%) is presented in Table 3, showing that the usual amounts in pharmaceutical formulations did not interfere in captopril determination by the proposed procedure.

Table 3. Maximum tolerated concentrations (inference lower than 5\%) of concomitants species in captopril determination

\begin{tabular}{lc}
\hline Species & $\begin{array}{c}\text { Maximum tolerated } \\
\text { concentration } /\left(\mathrm{g} \mathrm{L}^{-1}\right)\end{array}$ \\
\hline Lactose & 12.6 \\
Glucose & 6.3 \\
Sucrose & 6.0 \\
Starch & 2.0 \\
Stearic Acid & 2.0 \\
Magnesium stearate & 2.0 \\
Microcrystalline cellulose & 2.0 \\
\hline
\end{tabular}

Zone sampling

The zone sampling approach was evaluated to implement on-line sample dilution, exploiting the flow system in Figure 2b. With this strategy, the coefficient of dispersion is defined by the volume of the loops $\mathrm{L}_{1}$ and $\mathrm{L}_{2}$ as well as the portion of the dispersed zone inserted in the carrier $\mathrm{C}_{2}$ (defined by the resting time of the injector in the injection position, $\mathrm{ts}_{1}$ ). Operational conditions were established to implement a 50-fold sample dilution (similar to the batch one) with experiments carried out with colored solutions (potassium permanganate). The results showed in Figure $5 \mathrm{a}$ and $\mathrm{b}$ indicate that the required dilution is attained when $\mathrm{ts}_{1}=19 \mathrm{~s}$, for $\mathrm{L}_{1}=50 \mu \mathrm{L}$ and $\mathrm{L}_{2}=300 \mu \mathrm{L}$. Under these conditions, precise sample dilution can be implemented (coefficient of variation $=0.9 \%$ ) as showed in Figure 5c.

\section{Sample analysis}

Samples were processed as described on item Sample preparation and then analyzed by the proposed procedure with batch and on-line dilution, as well as by the titrimetric procedure described in the United States Pharmacopeia. ${ }^{6}$ In accordance with a paired Student t-test, the results presented in Table 4 agreed with the obtained by the reference method at the $95 \%$ confidence level.

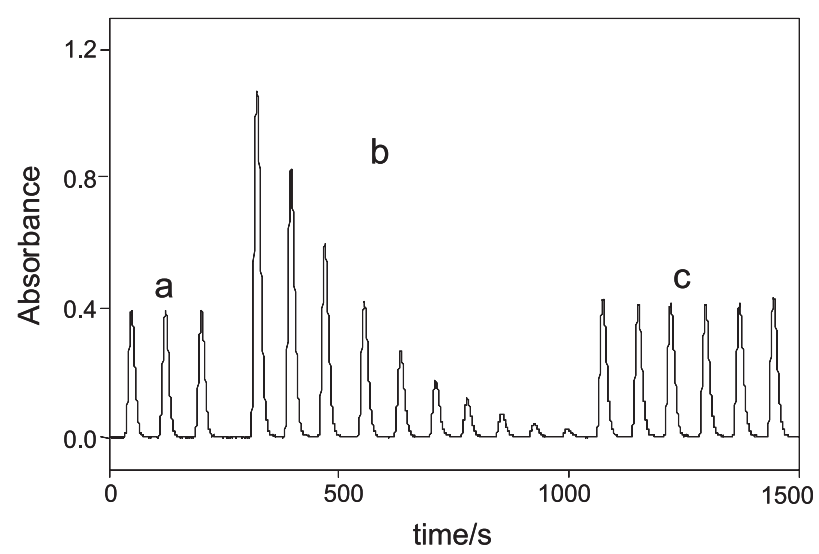

Figure 5. Zone sampling experiment with potassium permanganate solutions: (a) Transient signals obtained for $0.4 \mathrm{mmol} \mathrm{L}^{-1} \mathrm{KMnO}_{4}$ in the experimental conditions adopted in Figure 2a; (b) effect of ts $(16-25 \mathrm{~s})$ on sample dilution and (c) evaluation of repeatability for $\mathrm{ts}_{1}=19 \mathrm{~s}$. Experiments (b) and (c) were carried out with the flow system on Figure $2 \mathrm{~b}$ and $20 \mathrm{mmol} \mathrm{L}^{-1} \mathrm{KMnO}_{4}$.

Table 4. Captopril determination in commercial pharmaceutical samples

\begin{tabular}{ccccc}
\hline & \multicolumn{4}{c}{ Captopril amount / (mg per tablet) } \\
\cline { 2 - 4 } Sample & $\begin{array}{c}\text { Labeled } \\
\text { value }\end{array}$ & \multicolumn{2}{c}{ Proposed method } & Volumetric \\
\cline { 2 - 4 } method $^{6}$ & manual dilution & on-line dilution & vann \\
\hline 1 & 12.5 & $12.81 \pm 0.07$ & $12.62 \pm 0.07$ & $12.77 \pm 0.05$ \\
2 & 12.5 & $12.80 \pm 0.07$ & $11.86 \pm 0.05$ & $12.10 \pm 0.29$ \\
3 & 12.5 & $13.79 \pm 0.08$ & $13.01 \pm 0.10$ & $13.12 \pm 0.07$ \\
4 & 25 & $23.53 \pm 0.23$ & $27.41 \pm 1.15$ & - \\
5 & 50 & $51.03 \pm 0.08$ & - & $51.20 \pm 0.24$ \\
\hline
\end{tabular}

\section{Conclusions}

The proposed procedure is a simple, fast, greener and inexpensive alternative for routine analysis of captopril in pharmaceutical formulations, exploiting a chemistry similar to the used in the reference volumetric method. Analytical performance is comparable or better than the achieved in most of the flow-based procedures for determination of the anti-hypertensive. Common concomitants do not interfere even when in amounts significantly higher than the usual. The required reagents are commonly used in most laboratories, being consumed in micro-amounts and generating a low toxicity waste. On-line sample dilution can be implemented by the zone sampling approach, aiming processing directly the extracts of the pharmaceutical preparations.

\section{Acknowledgments}

The authors acknowledge the fellowship and financial support from the Brazilian Agencies Conselho Nacional de Desenvolvimento Científico e Tecnológico (CNPq) and 
Fundação de Amparo à Pesquisa do Estado de São Paulo (FAPESP).

\section{References}

1. Porth, C. M.; Pathophysiology: Concepts of Altered Health States, $7^{\text {th }}$ ed., Lippincott Williams \& Wilkins: Philadelphia, 2005.

2. Kohlmann Jr., O.; Guimarães, A. C.; Carvalho, M. H. C.; Chaves Jr., H. C.; Machado, C. A.; Praxedes, J. N.; Santello, J. L.; Arq. Bras. Endocrinol. Metab. 1999, 43, 257.

3. Rang, H. P.; Dale, M. M.; Ritter, J. M.; Moore, P. K.; Pharmacology, $4^{\text {th }}$ ed., Churchill Livingstone: New York, 2001.

4. Katzung, B. G.; Basic and Clinical Pharmacology, $9^{\text {th }}$ ed., McGraw Hill: New York, 2004.

5. Page, C.; Curtis, M.; Sutter, M.; Walker, M.; Hoffman, B.; Integrated Pharmacology, $2^{\text {nd }}$ ed., Mosby: New York, 2002.

6. The United States Pharmacopeia, USP 28, The United States Pharmacopeial Convention, Rockville, 2004.

7. Rocha, F. R. P.; Nóbrega, J. A.; Fatibello-Filho, O.; Green Chem. 2001, 3, 216.

8. Melchert, W. R.; Infante, C. M. C.; Rocha, F. R. P.; Microchem. J. 2007, 85, 209.

9. Albero, M. I.; Sánchez-Petreño, C.; Garciá, M. S.; Ródenas, V.; J. Pharm. Biomed. Anal. 1993, 11, 887.

10. Suarez, W. T.; Madi, A. A.; Figueiredo-Filho, L. C. S.; FatibelloFilho, O.; J. Braz. Chem. Soc. 2007, 18, 1215.

11. Tzanavaras, P. D.; Themelis, D. G.; Economou, A.; Theodoridis, G.; Talanta 2002, 57, 575.
12. Tzanavaras, P. D.; Themelis, D. G.; Economou, A.; Theodoridis, G.; Microchim. Acta 2003, 142, 55.

13. Prior, J. A. V.; Santos, J. L. M.; Lima, J. L. F. C.; Anal. Chim. Acta 2007, 600, 183.

14. Du, J.; Li, Y.; Lu, J.; Luminescence 2002, 17, 165.

15. Economou, A.; Themelis, D. G.; Theodoridis, G.; Tzanavaras, P. D.; Anal. Chim. Acta 2002, 463, 249.

16. Pulgarín, J. A. M.; Bermejo, L. F. G.; López, P. F.; Anal. Chim. Acta 2005, 546, 60.

17. Song, Z.; Hou, S.; Yu, X.; Xie, X.; Shao, X.; Anal. Lett. 2006, $39,1115$.

18. Li, Y.; Zhang, A.; Du, J.; Lu, J.; Anal. Lett. 2003, 36, 871.

19. Li, B.; Zhang, Z.; Wu, M.; Microchem. J. 2001, 70, 85.

20. Zheng, X.; Zhang, Z.; Li, B.; Electroanalysis 2001, 13, 1046.

21. Zhang, Z. D.; Baeyens, W. R. G.; Zhang, X. R.; van der Weken, G.; J. Pharm. Biomed. Anal. 1996, 14, 939.

22. Palomeque, M. E.; Band, B. S. F.; J. Pharm. Biomed. Anal. 2002, 30, 547.

23. Reis, B. F.; Jacintho, A. O.; Mortatti, J.; Krug, F. J.; Zagatto, E. A. G.; Bergamin-Filho, H.; Pessenda, L. C. R.; Anal. Chim. Acta 1981, 123, 221.

24. Analytical Methods Committee, Analyst 1987, 112, 199.

25. Mestre, Y. F.; Zamora, L. L.; Calatayud, J. M.; Luminescence 2001, 16, 213.

Received: August 29, 2008

Web Release Date: December 12, 2008

FAPESP helped in meeting the publication costs of this article. 